\title{
Partial characterization, antioxidative properties and hypolipidemic effects of oilseed cake of Allanblackia floribunda and Jatropha curcas
}

\author{
Thaddée Boudjeko ${ }^{1,2^{*}}$, Judith Emery Kanemoto Ngomoyogoli ${ }^{1}$, Alice Louise Woguia ${ }^{2}$ and Nicolas Njintang Yanou ${ }^{3}$
}

\begin{abstract}
Background: High fat diet is known to induce oxidative stress and abnormal changes in lipid metabolism. Many traditional plants have been shown to possess antioxidant and lipid-lowering activities, improving on oxidative status and lipid profile. In this paper, we characterized and examined the antioxidative properties of the oilseed cake of A. floribunda and J. curcas. We also evaluated their effect on lipid profile in the plasma and liver of experimental rats placed on a high fat diet.
\end{abstract}

Methods: For a partial characterization, the qualitative and quantitative analyses of storage proteins, dietary fibre and polyphenol content were evaluated. Four extracts (aqueous, ethanolic, methanolic and $0.1 \mathrm{~N} \mathrm{HCl}$ ) were evaluated for their antioxidant properties and scavenging activities. The effect on lipid profile was evaluated after the administration of the crude extracts to albino rats placed on a high fat diet.

Results: Our results showed that $J$. curcas contains 10 times more storage proteins than A. floribunda while A. floribunda contains twice as much total dietary fibre than J. curcas. An evaluation of the different families of storage proteins showed that J. curcas has glutelins as the major storage proteins in its seeds $(61.65 \mathrm{mg} / \mathrm{g} \mathrm{d} . \mathrm{m})$, followed by globulins ( $25.30 \mathrm{mg} / \mathrm{g} \mathrm{d.m}$ ) and albumins ( $18.30 \mathrm{mg} / \mathrm{g} \mathrm{d.m}$ ). The electrophoretic analyses revealed a diversity of bands at the level of the different families and for both species. The evaluation of the in vitro antioxidant activities showed that A. floribunda extracts had higher antioxidant properties. Although the composition of A. floribunda and J. curcas oilseed cake are different, they lowered serum triglycerides (TG), total cholesterol (TC) and blood glucose level.

Conclusion: These results show that the oilseed cake of A. floribunda and J. curcas possess antioxidant properties with an effect on blood glucose level and lipid profile.

Keywords: A. floribunda, J. curcas, Oilseed cake, Antioxidant and scavenging activities, Lipid profile

\section{Background}

Hypercholesterolemia and hypertriglyceridemia are major risk factors that, alone or together, can accelerate the development of coronary artery diseases and the progression of atherosclerotic lesions [1]. Normally, the major part of cholesterol serves as structural element in the cell membranes, whereas much of the rest is in transit through

\footnotetext{
* Correspondence: boudjeko@yahoo.com

'Laboratory of Phytoprotection and Valorisation of Plants Resources, Biotechnology Centre - Nkolbisson, P.O. BOX 3851, Messa, Yaounde, Cameroon

${ }^{2}$ Department of Biochemistry, Faculty of Science, University of Yaounde I, P.O. BOX 3851, Messa, Yaounde, Cameroon

Full list of author information is available at the end of the article
}

the blood or functions as the starting material for the synthesis of bile acids in the liver, steroid hormones in endocrine cells, or vitamin D in the skin. However, high levels of cholesterol accumulate in the extracellular subendothelial space of arteries and are modified to form oxidized LDL, which is highly atherogenic and toxic to vascular cells [2]. LDL levels in blood have been associated to a variety of chronic diseases such as atherosclerosis, hypertension, obesity, diabetes, functional depression of some organs, etc..... In addition, there is a relationship between hyperlipidemia (hypercholesterolemia) and the increased production of oxygen free radicals and the antioxidative defense system [3,4]. In fighting against metabolic 
disorders, some naturally occurring compounds with antioxidative properties may have beneficial effects on the overall disease processes [5]. Jatropha curcas and Allanblackia floribunda are two tropical plants shrubs which fall within this scope.

Jatropha curcas L. (physic nut, purging nut or pig nut), belonging to the family of Euphorbiaceae, is currently used worldwide industrially for the production of biodiesel. Besides, it is also used in traditional folklore medicine to cure various ailments in Africa, Asia and Latin America [6,7]. The crude ethanolic extract of the leaves has shown antimicrobial properties against many bacteria including Staphylococcus spp., Streptococcus spp. and E. coli [8]. The water extract of the branches strongly inhibits HIV induced cytopathic effects with low cytotoxicity [6]. The leaves of J. curcas contain apigenin, vitexin and isovitexin which along with other factors enable them to be used against malaria, rheumatic and muscular pains [9].

Allanblackia floribunda Oliver, commonly known as tallow-tree or ouotera, is a member of the mangosteen family (Guttiferae Juss. 1789 vs. Clusiaceae Lindl. 1836). The bark of $A$. floribunda is used against cough, dysentery, diarrhea, toothache, and is an analgesic [10]. The stem bark extract possesses aphrodisiac, antihypertensive and antioxidant properties [11]. Moreover, the seeds are rich in a hard white fat (67-73\%) consisting mostly of stearic and oleic acids [12]. Oleic and stearic acids are reported to lower plasma cholesterol levels [13], thus reducing the risks of heart attack. Owing to this property, A. floribunda seed fat is used for margarine production and in the manufacture of soap and ointments [14].

Whatever limited information available on the medicinal properties of $J$. curcas and A. floribunda is mostly on the leaf extracts, latex, oil or stem bark of the plant. In this paper, we examined the antioxidative properties of oilseed cake of A. floribunda and J. curcas. We also evaluated their effect on lipid profile in the plasma and liver of experimental rats placed on a high fat diet.

\section{Methods}

\section{Plant material}

Dry seeds of $A$. floribunda (Voucher N: $1380 / \mathrm{CNH}$ ) and J. curcas (Voucher N: 25713/CNH) were collected from the Centre and North regions of Cameroon respectively in September 2010 and authenticated by the Cameroon National Herbarium. Upon collection, the identities of the plants were determined by the Cameroon National Herbarium in Yaounde. The dried seeds were finely ground and defatted with hexane by exhaustion.

\section{Proteins extraction and analyses}

Storage protein fractions were extracted from defatted powder according to Nasri and Triki [15]. $15 \mathrm{mg}$ of residue were mixed with $1 \mathrm{~mL}$ distilled water at $4^{\circ} \mathrm{C}$ for $1 \mathrm{hr}$ and then centrifuged at $10000 \mathrm{~g}$ for $20 \mathrm{~min}$ at the same temperature. The supernatant containing albumins was collected, while the pellet was used in further extractions. In this respect the pellet was rinsed with $0.5 \mathrm{~mL}$ distilled water before a $30 \mathrm{~min}$ homogenization, followed by centrifugation under the same conditions as in the previous step, to remove albumins completely. The pellet obtained, underwent a similar series of steps (homogenization-centrifugation, rinsing) using a mixture of $100 \mathrm{mM}$ Tris $\mathrm{HCl}$ in $0.5 \mathrm{M} \mathrm{NaCl}$ at $\mathrm{pH} 8.1$ to extract globulins. The second pellet was submitted to a third and similar extraction of prolamins in $70 \%$ ethanol, and glutelins in acetic acid $0.2 \mathrm{~N}$. The four protein groups obtained were quantified by the Bradford method [16]. The protein bands were then determined using SDSPAGE (12\%, pH 8.8) according to the method of Laemmli [17]. The estimation of molecular weight was done based on the Pre-stained Protein Marker, Broad Range P7708S. At the end of the migration, gels obtained were immerged for $2 \mathrm{hrs}$, in a staining solution made up of methanol/ acetic acid/distilled water (50/10/40, v/v/v) and $0.25 \%$ Coomassie Brillant Blue R-250. After staining, the gel with protein bands were snapped using a numeric photo apparatus (Samsung) to produce the electrophoregrammes.

\section{Total dietary fibres content}

Total dietary fibre content was estimated using a modified AOAC 2000 [18] method. 2 g of defatted powder were added to $10 \mathrm{~mL}$ of $\alpha$-amylase (Sigma Chemical Co. Ltd) $2 \%$ in phosphate buffer $0.1 \mathrm{M} \mathrm{pH} 7$ and protease. Then, the residue was rinsed with $20 \mathrm{~mL}$ of boiling water and a cold solution of amyloglucosidase (EC: 3.2.1.1 Megazyme International) was added. A solution of $80 \%$ ethanol was added and the mixture filtered and rinsed with boiling water. The residue was weighted and used for the quantification of ashes and proteins.

\section{Antioxidant properties}

The antioxidant properties of the defatted powders were evaluated on different solvent extracts: water, ethanol (70\%), methanolic (80\%) and $0.1 \mathrm{~N} \mathrm{HCl}$, as described by Dicka et al. [19]. One gram of defatted powders was extracted in $20 \mathrm{ml}$ of respective solvents in a Soxhlet apparatus for $24 \mathrm{~h}$. The extracts were centrifuged and filtered for antioxidant properties.

\section{Total phenolic content}

The amount of total phenolic compounds in extracts was determined using Folin-Ciocalteu reagent, according to the method of Singleton and Rossi [20] with some modifications and using ferulic acid as a standard. Briefly, $500 \mu \mathrm{L}$ of extract solution were added to $1500 \mu \mathrm{L}$ of distilled water then $75 \mu \mathrm{L}$ of Folin-Ciocalteu reagent and 
mixed thoroughly. After $3 \mathrm{~min}, 750 \mu \mathrm{L} \mathrm{Na} \mathrm{CO}_{3}$ (20\%) were added. The mixture was allowed to stand for $1 \mathrm{~h}$ with intermittent shaking. The absorbance was measured at $760 \mathrm{~nm}$ using a visible spectrophotometer. The total phenolic content was expressed as $\mathrm{mg}$ of ferulic acid equivalent per g of dry matter, using a standard curve prepared using ferulic acid.

\section{Ferric reducing antioxidant potential (FRAP) assay}

The ferric reducing power of plant extracts was determined using a modified Benzie and Strain [21] method. Essentially the FRAP reagent containing 1 volume of $10 \mathrm{mmol} / \mathrm{L}$ TPTZ (2, 4, 6- tripyridyl- $\mathrm{s}$ - triazine) solution in $40 \mathrm{mmol} / \mathrm{L} \mathrm{HCl}, 1$ volume of $20 \mathrm{mmol} / \mathrm{L} \mathrm{FeCl}_{3}$ and 10 volume of $0.3 \mathrm{~mol} / \mathrm{L}$ acetate buffer $(\mathrm{pH}=3.6)$ was prepared freshly. Aliquots of $100 \mu \mathrm{L}$ extract $(1000 \mu \mathrm{g} / \mathrm{mL})$ were mixed with $2 \mathrm{~mL}$ FRAP reagent and the absorbance of the reaction mixture at $593 \mathrm{~nm}$ was measured spectrophotometrically after incubation at $37^{\circ} \mathrm{C}$ for $12 \mathrm{~min}$. For construction of the standard curve, 5 concentrations (1000, 750, 500, 250, $125 \mu \mathrm{mol} / \mathrm{L})$ of $\mathrm{FeSO}_{4}, 7 \mathrm{H}_{2} \mathrm{O}$ were used and the optical densities were measured as sample solution. The values were expressed as the concentration of antioxidants having a ferric reducing ability equivalent to that of $\mathrm{FeSO}_{4}$.

\section{DPPH free-radical-scavenging assay}

The method described by Katalinie et al. [22] was adopted. To $100 \mu \mathrm{L}$ of variable concentrations of the extract (100; 250 and $500 \mu \mathrm{g} / \mathrm{mL}$ ) was added $500 \mu \mathrm{L}$ DPPH solution (400 $\mu \mathrm{M}$ in methanol). The mixture was stirred and left in the dark for $30 \mathrm{~min}$. The absorbance was measured at
517 nm using UV-1605 Shimadzu spectrophotometer and ascorbic acid was used as the positive control.

\section{ABTS free-radical-scavenging assay}

The method described by Re et al. [23] was adopted. To $100 \mu \mathrm{L}$ of variable concentration of extract (100; 250 and $500 \mu \mathrm{g} / \mathrm{mL}$ ) was added ABTS reagent. The mixture was stirred and left in the dark for $30 \mathrm{~min}$. The absorbance was measured at $734 \mathrm{~nm}$ using UV-1605 Shimadzu spectrophotometer and ascorbic acid was used as the positive control.

\section{Chelating ability for ferrous ions}

The method of Dinis et al. [24] was used to determine the ferrous ion chelating ability. $100 \mu \mathrm{L}$ of different extracts (100; 250 and $500 \mu \mathrm{g} / \mathrm{mL}$ ) were mixed with $100 \mu \mathrm{L}$ of $2 \mathrm{mM} \mathrm{FeCl}_{2}$ and left in the dark for $30 \mathrm{~s}$. The mixture was added to $200 \mu \mathrm{L}$ of $5 \mathrm{mM}$ ferrozine. After $10 \mathrm{~min}$ at room temperature, the absorbance of the mixture was determined at $562 \mathrm{~nm}$ against a blank. A lower absorbance indicated a higher chelating power and EDTA was used as the positive control.

In vivo study of hypolipidemic effect of defatted products Investigations on animals were conducted in accordance with the internationally accepted principles for laboratory animal use and care as found in the United States guidelines (United States National Institutes for Health publication $\mathrm{n}^{\circ}$ 85-23 revised in 1985). The animals were maintained under standard laboratory conditions with $12 \mathrm{~h}$ light and dark cycle, with free access to standard laboratory rat food and tap water (temperature of $24 \pm 1^{\circ} \mathrm{C}$

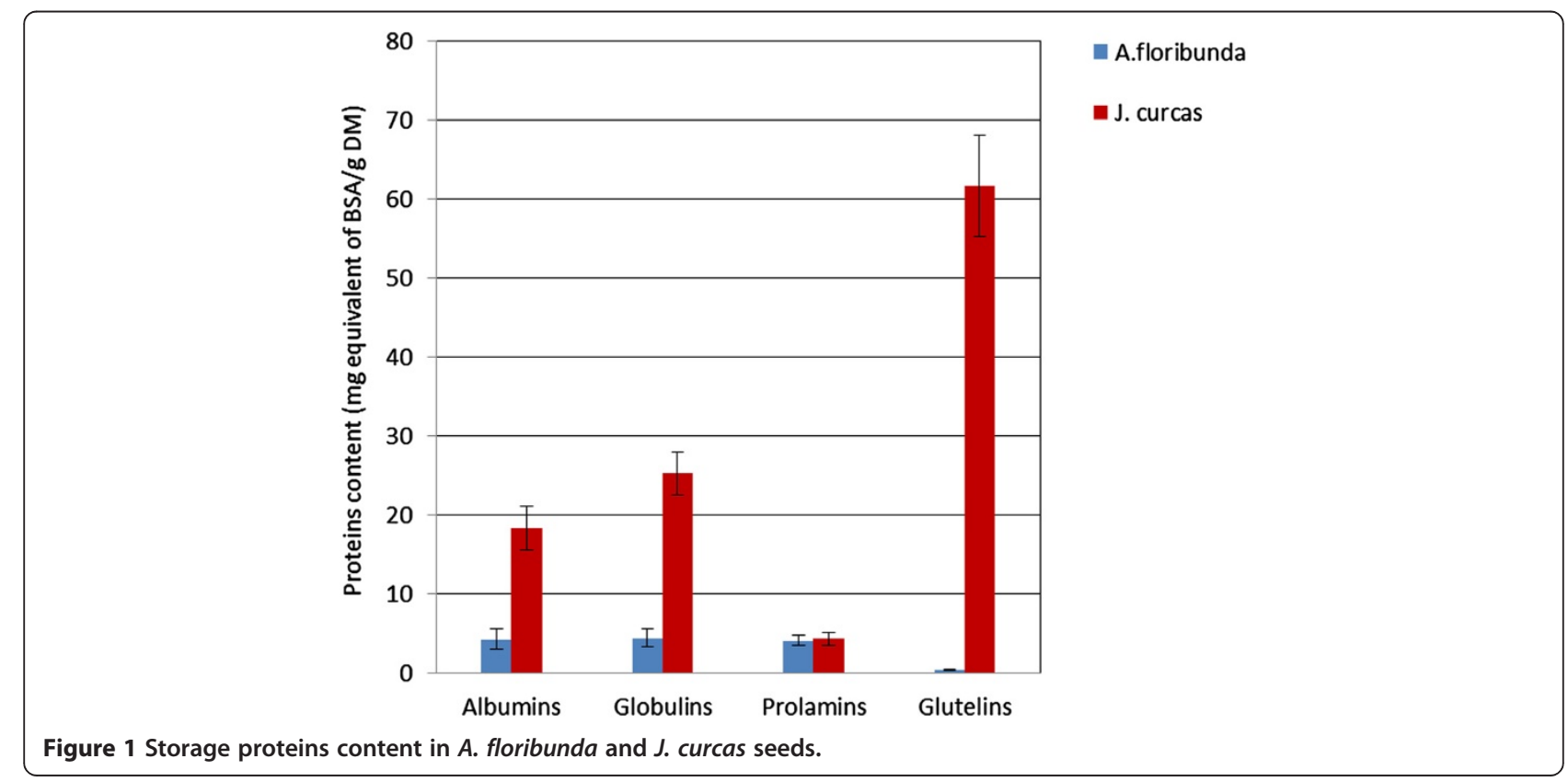




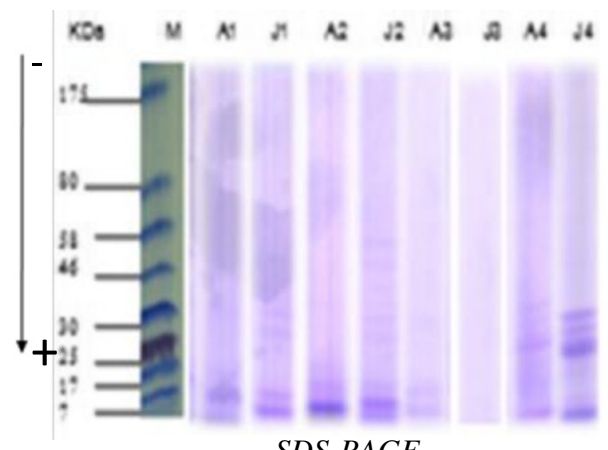

SDS-PAGE

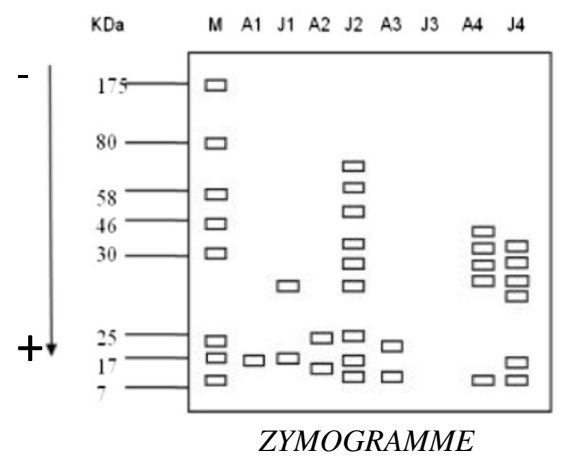

Figure 2 Different sub-units of storage proteins. $a=$ electrophoregramme; $b=$ zymogramme; $M=$ molecular marker; $A=A$. floribunda; $\mathrm{J}=\mathrm{J}$. curcas; 1 = albumin; 2 = globulin; 3 = prolamin; 4 = glutelin.

and humidity of $55 \pm 10 \%$ ). Prior authorization for the use of laboratory animals in this study was obtained from the Cameroon National Ethical Committee.

Twenty male Wistar rats (180-210 g) bred in the laboratory were randomly divided into four groups of five rats each and then housed separately in partitioned polypropylene cages labeled as control, high fat diet control, high fat diet treated $+250 \mathrm{mg} \cdot \mathrm{kg}^{-1}$ A. floribunda extract; high fat diet treated $+250 \mathrm{mg} \cdot \mathrm{kg}^{-1} \mathrm{~J}$. curcas extract. The rats were allowed free access to water and feed (diet) ad libitum for 15 days under controlled environmental conditions of temperature and relative humidity and a 12-hour light and dark cycle. Treatment was administered daily by force-feeding with water for control group and high fat diet group, $100 \mathrm{mg}$. $\mathrm{mL}^{-1}$ of aqueous crude extract of A. floribunda or J. curcas at dose of $250 \mathrm{mg}$ per $\mathrm{kg}$ body weight of experimental animals respectively. The control group was fed the normal diet while the high fat diet treated rats were fed with high fat diet, containing $23 \mathrm{~g}$ of casein, $5 \mathrm{~g}$ of cellulose, $10 \mathrm{~g}$ of sucrose, $46 \mathrm{~g}$ of starch, $10 \mathrm{~g}$ of lard, $4 \mathrm{~g}$ of corn oil and $0.15 \mathrm{~g}$ of margarine.

\section{Sample collection}

On the last day of the experiment, rats were deprived of food for $12 \mathrm{~h}$ and then anaesthetized by ether inhalation and sacrificed by decapitation. Blood was collected from the heart into EDTA tubes. Plasma was prepared by centrifugation at 3,000 rpm for 15 minutes (Clay-Adams Co. Inc. centrifuge, New York, USA) and used for the estimation of lipid profile. Livers from the animals were rinsed in ice-cold $1.15 \% \mathrm{KCl}$, dried and weighed. It was homogenized in 4 volumes of ice-cold $50 \mathrm{mM}$ phosphate buffer, $\mathrm{pH}$ 7.4, and centrifuged at 6,000 rpm (Clay-Adams Co. Inc. centrifuge, New York, USA) for 20 min to obtain post mitochondrial fraction (PMF). Total cholesterol (TC) and triglycerides (TG) were determined enzymatically using commercially available kits from Chronolab and blood glucose level was measured after $18 \mathrm{hrs}$ of fasting on day 0 and day 14 .

\section{Statistical analyses}

The results were expressed as mean \pm standard deviation of three parallel measurements; the Kruskal Wallis test was used to evaluate the significance of the variation amongst the test group, and when this was verified, a Least Significant Difference (LSD) test was used to compare two means. The level of significance was set at $p<0.05$ and the graphical representations were designed in Microsoft Excel 2007.

\section{Results}

\section{Protein extraction and analysis}

The composition of proteins showed considerable differences between the two species (Figure 1). In general, the total protein content was higher in $J$. curcas than A. floribunda. Glutelins $(61.65 \mathrm{mg} / \mathrm{g}$ dry mass (d.m)) were the predominant proteins in J. curcas followed by globulins $(25.30 \mathrm{mg} / \mathrm{g}$ d.m) and albumins $(18.30 \mathrm{mg} / \mathrm{g}$ d.m). However, in A. floribunda seeds globulins (4.37 mg BSA/g d.m), albumins (4.24 mg BSA/g d.m) and prolamins (4.12 $\mathrm{mg} \mathrm{BSA} / \mathrm{g}$ d.m) had similar amounts.

Table 1 Total phenolic content and FRAP antioxidant capacities

\begin{tabular}{lcc}
\hline Extracts & A. floribunda & J. curcas \\
\hline \multicolumn{2}{l}{ Total phenolic content $(\mathbf{m g}$ equivalent of ferulic acid/g d.m) } \\
Aqueous & $47.17 \pm 2.01^{\mathrm{a}}$ & $43.93 \pm 2.98^{\mathrm{a}}$ \\
Ethanolic & $62.69 \pm 7.20^{\mathrm{a}}$ & $66.64 \pm 0.12^{\mathrm{a}}$ \\
Methanolic & $54.39 \pm 0.20^{\mathrm{b}}$ & $31.54 \pm 2.39^{\mathrm{a}}$ \\
$\mathrm{HCl} 0.1 \mathrm{~N}$ & $15.38 \pm 0.56^{\mathrm{a}}$ & $18.8 \pm 0.01^{\mathrm{a}}$
\end{tabular}

FRAP antioxidant capacities ( $\mathrm{mg}$ equivalent of ascorbic acid/g d.m)

Aqueous $\quad 11.02 \pm 0.08^{\mathrm{b}} \quad 5.03 \pm 0.42^{\mathrm{a}}$

Ethanolic $\quad 21.80 \pm 0.50^{\mathrm{b}} \quad 7.70 \pm 0.44^{\mathrm{a}}$

Methanolic $\quad 15.82 \pm 0.48^{\mathrm{b}} \quad 2.85 \pm 0.55^{\mathrm{a}}$

$\begin{array}{lll}\mathrm{HCl} 0.1 \mathrm{~N} & 3.72 \pm 0.04^{\mathrm{a}} & 3.85 \pm 0.01^{\mathrm{a}}\end{array}$

Data are presented as mean $\pm S D(n=5)$; mean values within a line with different superscript letters are statistically different $(p<0.05)$. d.m: dry mass. 


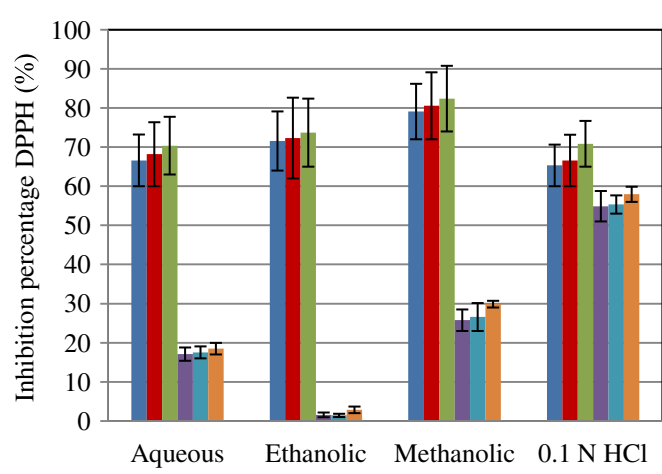

- A. floribunda $0.1 \mathrm{mg} / \mathrm{mL}$

- A. floribunda $0.25 \mathrm{mg} / \mathrm{mL}$

A. floribunda $0.5 \mathrm{mg} / \mathrm{mL}$

- J. curcas $0.1 \mathrm{mg} / \mathrm{mL}$

- J. curcas $0.25 \mathrm{mg} / \mathrm{mL}$

J. curcas $0.5 \mathrm{mg} / \mathrm{mL}$

Figure 3 DPPH radical scavenging activity in different extracts of seeds oil-cake of $A$. floribunda and $J$. curcas.

The electrophoretic analysis by SDS-PAGE showed bands with molecular weight ranging from 7 to $64 \mathrm{kDa}$ (Figure 2). J. curcas had the highest diversity in globulin sub-types, with 9 bands $(7.3 ; 8.43 ; 14.79 ; 25.47 ; 27.18$; $29.85 ; 47.8 ; 54.3$ and $64 \mathrm{kDa})$, followed by glutelins, 6 bands (7; 8.3; 25.4; 25.7; 26.31; and $27.58 \mathrm{kDa}$ ). A. floribunda contained globulins with only two sub-units (9 and $15 \mathrm{KDa}$ ), albumins with one sub-unit of 13.4 KDa, prolamins with two bands $(7.03$ and $14.12 \mathrm{kDa})$ and glutelins with five bands $(7 ; 25.71 ; 26.31 ; 27.58$ and $29.19 \mathrm{KDa})$ (Figure 2).

\section{Total dietary fibres}

Total dietary fibres estimated by enzymatic procedure were higher in A. floribunda (49.57\%) than J. curcas (24.47\%).

Total phenolic content and FRAP antioxidant capacities

The total phenolics compounds and FRAP antioxidant capacity of $A$. floribunda and J. curcas extracts obtained from various solvents are presented in Table 1. Generally, ethanol extracted more phenolic compounds than methanol and water (Table 1). The difference between $J$. curcas and A. floribunda was observed only with the methanolic extract which was significantly higher in
A. floribunda than J. curcas. On the contrary, the FRAP antioxidant capacity was systematically higher in all extracts of $A$. floribunda than $J$. curcas except $\mathrm{HCl}$. The ethanolic extract was ranked first $(21.80 \pm 0.50 \mathrm{mg} / \mathrm{g} \mathrm{d}$. $\mathrm{m})$ followed by methanolic $(15.82 \pm 0.48 \mathrm{mg} / \mathrm{g} \mathrm{d} . \mathrm{m})$ and aqueous (11.02 $\pm 0.08 \mathrm{mg} / \mathrm{g} \mathrm{d} . \mathrm{m})$ extracts (Table 1 ).

\section{DPPH and ABTS free-radical-scavenging assay}

The results showed that the DPPH scavenging capacity (Figure 3 ) of the $A$. floribunda extract was higher than that of the J. curcas and increased with increasing extract concentrations. Moreover, A. floribunda had the highest $\mathrm{DPPH}$ scavenging activity in the methanolic fraction, while in J. curcas the highest activity was obtained with the $0.1 \mathrm{~N} \mathrm{HCl}$ fraction. With ABTS, the inhibition percentage fluctuated between $78.9 \pm 0.98 \%$ and $80.2 \pm 0.05 \%$ for A. floribunda while in J. curcas it fluctuated between $11.8 \pm 1.65 \%$ and $69.5 \pm 2.44 \%$. Irrespective of the plant nature, the aqueous extract had the highest (Figure 4).

\section{Chelating capability for ferrous ions}

Metal $(\mathrm{Fe} 2+)$ chelating activity (Figure 5) showed that A. floribunda at the concentrations tested (0.1, 0.25 and $0.5 \mathrm{mg} / \mathrm{mL}$ ) had a larger percentage of metal-chelating capacity than J. curcas.

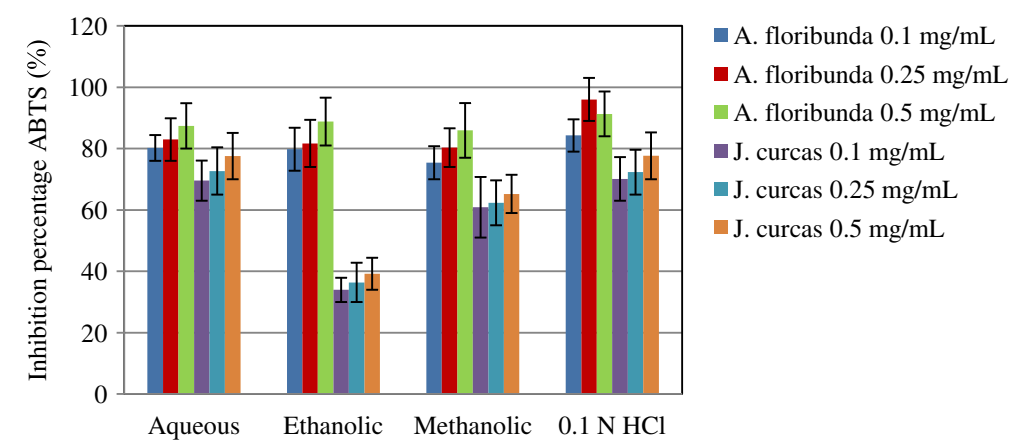

Figure 4 ABTS radical scavenging activity in different extracts of seeds oil-cake of $A$. floribunda and $J$. curcas. 


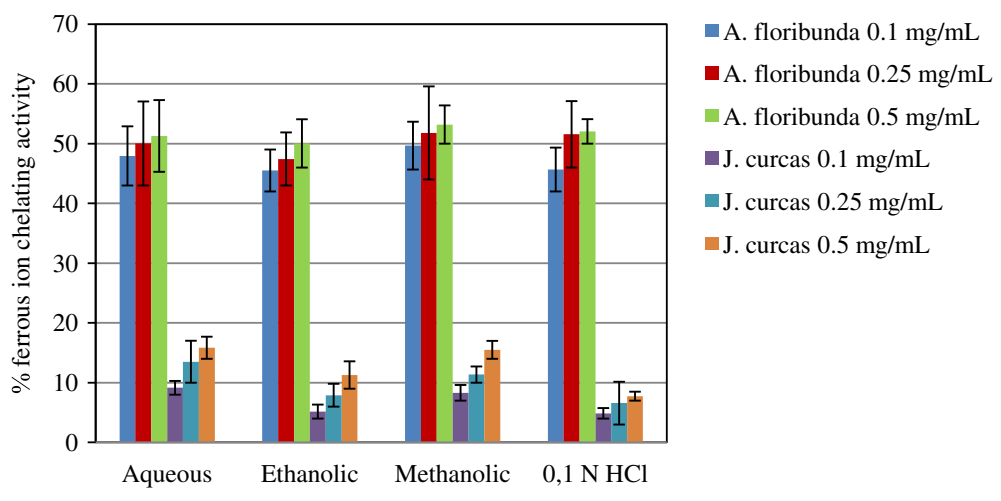

Figure $\mathbf{5}$ Iron metal ions chelating activity in different extracts of seeds oil-cake of $A$. floribunda and J. curcas.

Food intake, weight gain, serum lipid level and hypoglycemic activity

Hyperlipidemia and hyperglycemia were induced by administering high fat diet to rats. The administration of high fat diet to the rats affected the mean food intake and body weight gain of the animals in different ways depending on the experimental groups (Table 2). In the animals fed with high fat diet, $A$. floribunda and J. curcas led to significant $(p<0.05)$ decrease in total food intake as compared to the controls. Moreover, the body weight varied significantly $(p<0.05)$ between the groups at the end of the 14-day experience. Weight gain throughout the highfat treatment was significantly $(p<0.05)$ lower in the animals that received $A$. floribunda and J. curcas than in those that received the high-fat diet only (Table 2). To investigate the effect of the oilseed cakes of A. floribunda and $J$. curcas on the lipid levels of rat serum and the post mitochondrial fraction (PMF) of liver, the amounts of total cholesterol (TC) and triglycerides (TG) were measured. The results showed that rats fed with high fat diet in the absence of the plant extracts had their amounts of TG and $\mathrm{TC}$ in plasma increased by $31.7 \%$ and $47.2 \%$ respectively compared to the control, while in the liver, the increase was $39.0 \%$ and $41.0 \%$ (Table 3 ). The amounts of plasma TC and TG significantly $(p<0.05)$ decreased after the administration of oilseed cake of A. floribunda and J. curcas. For instance, the levels of plasma TC and TG reduced by $13.06 \%$ and $30.52 \%$ respectively for rats that received A. floribunda; and $18.57 \%$ and $13.42 \%$ for those that received $J$. curcas compared to the high fat diet group
(Table 3). However, in the post mitochondrial fraction (PMF) of the liver, the amounts of TC significantly decreased after administration of oilseed cake while the amounts of TG increased compared to the control group (Table 3). The induced hyperglycaemia, caused by administering high fat diet to rats, decreased statistically in all the test groups after 14 days (Table 4). This decrease is significantly more pronounced with $J$. curcas oilseeds cake than those of A. floribunda.

\section{Discussion}

The objectives of this research were to study the protein profile and antioxidant properties of oilseed cake generated from A. floribunda and J. curcas, as well as their effects on weight gain and serum lipid levels in experimental rats placed on a high fat diet. The solubilization of storage proteins in oilseed cake according to Nasri and Triki [15] method and their quantification using the Bradford [16] method show that A. floribunda was poorer in proteins and richer in dietary fibre when compared to conventional oilseed cakes which generally contain $35-45 \%$ of dried weight [25]. Another particularity was that glutelins were the major protein family in J. curcas, while in A. floribunda glutelins were at a non-detectable level. This result contrasted with findings by Rabetafika et al. [25] who found that globulins are the major protein family (58-68\%) of flax oilseed cake. The level of dietary fibre obtained for $J$. curcas $(24.47 \%)$ in this work is different from 10.12\% reported earlier by Akintayo [26] working on cultivars from Nigeria. The observed differences

Table 2 Nutritional parameters

\begin{tabular}{llll}
\hline & High fat diet & Control & A. floribunda \\
\hline Body gain $(\mathrm{g})$ & $65 \pm 3.08^{c}$ & $49.20 \pm 3.03^{\mathrm{b}}$ & $33.49 \pm 4.75^{\mathrm{a}}$ \\
Food intake $(\mathrm{g})$ & $302.60 \pm 9.63^{\mathrm{b}}$ & $339.20 \pm 8.40^{c}$ & $29.20 \pm 6.36^{\mathrm{a}}$ \\
Water intake $(\mathrm{mL})^{\text {Food efficiency }(\%)}$ & $415.80 \pm 13.42^{\mathrm{d}}$ & $555.60 \pm 15.22^{c}$ & $238.80 \pm 9.40^{\mathrm{a}}$ \\
\hline
\end{tabular}

Data are presented as mean \pm SD $(n=5)$; mean values within a line with different superscript letters are statistically different $(p<0.05)$. 
Table 3 Effect of seeds oil-cake on lipid profiles (in brackets represent \% of change)

\begin{tabular}{|c|c|c|c|c|c|}
\hline & & High fat diet & Control & A. floribunda & J. curcas \\
\hline & & $223.91 \pm 20.4^{a}$ & & $194.65 \pm 6.85^{\mathrm{b}}$ & $182.31 \pm 6.59^{b}$ \\
\hline & $\mathrm{TC}(\mathrm{mg} / \mathrm{dL})$ & $(31.71 \pm 4.30)$ & $170 \pm 5.44^{c}$ & $(13.06 \pm 0.96)$ & $(18.57 \pm 1.3)$ \\
\hline & & $228.03 \pm 16.32^{a}$ & & $158.42 \pm 4.57^{c}$ & $197.42 \pm 5.48^{b}$ \\
\hline \multirow[t]{4}{*}{ Plasma } & $\mathrm{TG}(\mathrm{mg} / \mathrm{dL})$ & $(47.17 \pm 3.04)$ & $156.22 \pm 4.36^{c}$ & $(30.52 \pm 1.52)$ & $(13.42 \pm 2.32)$ \\
\hline & & $227.30 \pm 15.76^{a}$ & & $182.9 \pm 4.5^{c}$ & $199.00 \pm 6.1^{b}$ \\
\hline & $\mathrm{TC}(\mathrm{mg} / \mathrm{dL})$ & $(39.02 \pm 3.70)$ & $163.5 \pm 3.61^{d}$ & $(19.53 \pm 2.05)$ & $(12.45 \pm 1.85)$ \\
\hline & & $252.91 \pm 11.33^{\mathrm{a}}$ & & $361.41 \pm 7.76^{b}$ & $356.68 \pm 8.52^{\mathrm{b}}$ \\
\hline Liver (post mitochondrial fraction (PMF) & $\mathrm{TG}(\mathrm{mg} / \mathrm{dL})$ & $(41.03 \pm 4.21)$ & $177.16 \pm 2.93^{c}$ & $(42.90 \pm 3.60)$ & $(41.03 \pm 2.36)$ \\
\hline
\end{tabular}

Values in the same row with identical superscripts are not significantly different $(p<0.05) . \%$ change was calculated using formula $\%$ change $=[(\mathrm{Tt}-\mathrm{Tc}) / \mathrm{Tc}] \times 100$, $\mathrm{Tt}=$ values of treated group, $\mathrm{Tc}=$ values of respective control group; Data are presented as mean \pm SD $(n=5)$; mean values within a line with different superscript letters are statistically different $(p<0.05) ; \mathrm{TC}=$ Total Cholesterol; TG = Triglycerides.

may be due to various possible factors such as genetic and environmental factors.

From Table 1, it was evident that the different solvents used for the extraction of phenolic compounds from A. floribunda and J. curcas oilseed cake, had different abilities to extract substances from these oilseed cake. In general, the extraction of phenolic compounds from A. floribunda and J. curcas oilseed cake with ethanol was found to be the most effective. These findings are not in agreement with those of Matthaüs [27] and Terpinc et al. [28] who found that extraction of phenols in various oilseed cakes with water was most effective as compared to alcohol and acid extraction.

Four antioxidant assays, namely Ferric Reducing Antioxidant Potential (FRAP), DPPH r radical scavenging activity, ABTS Free-Radical-Scavenging and ferrous ionchelating ability were performed in order to explore the antioxidant potential of the oilseed cakes of $A$. floribunda and J. curcas. Generally, extracts from A. floribunda oilseed cake demonstrated greater reducing power, antiradical power and iron-chelating capacity. It was noticed that the antioxidant potential of $A$. floribunda oilseed cake in DPPH assay was linearly correlated to its total phenolic compounds. These results are in accordance with the report that antioxidant activity increases proportionally with the polyphenol content $[29,30]$. Phenolic compounds are important phyto constituents and have potential against different diseases because of their antioxidant property

Table 4 Effect of seeds oil-cake on the blood glucose level ( $\mathrm{mg} / \mathrm{dL}$ ) (in brackets represent \% of change)

\begin{tabular}{lllll}
\hline & High fat diet & Control & A. floribunda & J. curcas \\
\hline Day 0 & $67.40 \pm 12.8^{\mathrm{a}}$ & $65.80 \pm 5.08^{\mathrm{a}}$ & $64.40 \pm 5.20^{\mathrm{a}}$ & $65.40 \pm 9.24^{\mathrm{a}}$ \\
Day 14 & $96.80 \pm 3.82^{\mathrm{a}}$ & $62.20 \pm 3.66^{\mathrm{b}}$ & $80.5 \pm 4.81^{\mathrm{d}}$ & $67.22 \pm 8.13^{\mathrm{c}}$ \\
& $(55.62 \pm 7.53)$ & & $(16.83 \pm 1.17)$ & $(30.57 \pm 3.21)$ \\
\hline
\end{tabular}

Values in the same row with identical superscripts are not significantly different $(p<0.05)$. \% change was calculated using formula \% change $=[(\mathrm{Tt}-\mathrm{Tc}) / \mathrm{Tc}] \times 100$, $\mathrm{Tt}=$ values of treated group, $\mathrm{Tc}=$ values of respective control group; Data are presented as mean $\pm S D(n=5)$; Mean values within a line with different superscript letters are statistically different $(p<0.05)$.
[31]. Radical scavenging via hydrogen atom donation by phenols is believed to be the predominant mechanism of antioxidant action [32]. However, no relationship was found between total phenol content and antioxidant efficiencies in J. curcas oilseed cake, suggesting that phenolic compounds are not the only contributors to the antioxidant activities of the $J$. curcas defatted cakes [28]. Furthermore, this observation are in line with those of Karadag et al. [33] who think that antioxidant and scavenging activities are hydroxyl functions content dependent.

The effect of oilseed cake of A. floribunda and J. curcas on the lipid profile and blood glucose level of rats placed on high fat diet suggested that they contributed to the regulation of serum TG and TC levels, blood glucose level and decreased dietary intake. These properties could be attributed to the presence of dietary fibres, phenolic compounds and storage proteins on oilseed cake. Generally, dietary fibres have a hypocholesterolaemic effect; modulate blood glucose response and increase satiety [34]. Furthermore, Marambe et al. [35] demonstrated the cholesterol-lowering property of flaxseed proteins by their bile acid binding ability. In the liver, the TC level decreased whereas the TG amount increased significantly. Liver is the main site of lipogenesis. Furthermore, the influence of food fatty acid composition on lipogenesis is well established [36]. The TG level which remained very high could be a consequence of the high fat consumed food.

\section{Conclusions}

The proteins group profile, antioxidant properties and total phenolic content of A. floribunda and J. curcas oilseed cake differed significantly from each other. This investigation also indicates that oilseed cake of $A$. floribunda and $J$. curcas possess hypolipidaemic effect and regulate blood glucose level. Additional studies are needed to characterize the mechanisms involved and toxicological effect, as it is well known that some J. curcas varieties seeds are highly toxic to some animal species due to the 
presence of toxins and antinutrient components. The present study supports the view that some plants are promising sources of natural antioxidants and are lipidlowering.

\section{Ethical considerations}

The studies were conducted in accordance with the internationally accepted principles for laboratory animal use and care as found in the United States guidelines (United States National Institutes for Health publication $n^{\circ}$ 85-23 revised in 1985) and approved by the Cameroon National Ethics Committee.

\section{Competing interest}

The authors declare that they have no competing interests.

\section{Authors' contributions}

TB conceived the project, participated in protein purification and supervised the work all through, JEKN participated in plant collection, protein purification and biological tests, ALW participated in phenols extraction and biological tests, NYN participated in work design and drafted the manuscript. All the authors proofread and approved the manuscript before submission.

\section{Acknowledgements}

The authors acknowledge the institutional and material support from the Biotechnology Centre of University of Yaounde I. TB is gratefully indebted to «Association des Universités et Collèges du Canada, AUCC» for financing exchange visits between Cameroon and Canada. Special thanks to Nono Borgia for his excellent technical assistance.

\section{Author details}

${ }^{1}$ Laboratory of Phytoprotection and Valorisation of Plants Resources, Biotechnology Centre - Nkolbisson, P.O. BOX 3851, Messa, Yaounde, Cameroon. ${ }^{2}$ Department of Biochemistry, Faculty of Science, University of Yaounde I, P.O. BOX 3851, Messa, Yaounde, Cameroon. ${ }^{3}$ Department of Biological Sciences, Faculty of Science, University of Ngaoundere, P.O. Box 454, Ngaoundere, Cameroon.

Received: 8 July 2013 Accepted: 5 December 2013

Published: 11 December 2013

\section{References}

1. Luscher TF, Tanner FC, Dohi Y: Age, hypertension and ypercholesterolaemia alter endothelium-dependent vascular regulation. Pharmacol Toxicol 1992, 70:32-39.

2. Catapano AL, Maggi FM, Tragni E: Low density lipoprotein oxidation, antioxidants, and atherosclerosis. Curr Opin Cardiol 2000, 15:355-363.

3. Amrani S, Harnafi H, Bouanani NH: Hypolipidaemic activity of aqueous Ocimum basilicum extract in acute hyperlipidaemia induced by Triton WR-1339 in rats and its antioxidant property. Phytother Res 2006, 20:1040-1045.

4. Woguia AL, Ngondi JL, Boudjeko T, Rihouey C, Oben EJ: Hypolipidemic and antioxidative effects of Dika nut (Irvingia gabonensis) seeds and nkui (Trimphetta cordifolia) Stem Bark mucilages in triton WR-1339 induced hyperlipidemic rats. Food Sci Biotechnol 2012, 21:1715-1721.

5. Boban PT, Bala N, Sudhakaran PR: Hypolipidaemic effect of chemically different mucilages in rats: a comparative study. Br J Nutr 2006, 96:1021-1029.

6. TI M, Lim YA, Hattori M, Correa M, Gupta MP: A search for anti-viral properties in Panamanian medicinal plants - the effect on hiv and essential enzymes. J Ethnopharmacol 1999, 64:15-22.

7. Aiyelaagbe OO: Antibacterial activity of Jatropha multifida roots. Fitoterapia 2001, 72:544-546.

8. Sharma A, Saxena S, Rani U, Rajore S, Batra A: Broad-spectrum antimicrobial properties of medicinally important plant Jatropha curcas L. Int J Pharma Sci Rev Res 2010, 4:11-14.

9. Thomas R, Sah NK, Sharma PB: Therapeutic biology of Jatropha curcas: a mini review. Cur Pharm Biotech 2008, 9:315-324.
10. Foma M, Abdala T: Kernel oils of seven species of Zaire. J Amer Oil Chem Soc 1985, 62:910-911.

11. Bilanda DN, Dimo T, Dzeufiet Djomenia PD, Ndzana M, Bella T, Aboubakar OBF, Nguelefack TB, Tan PV, Kamtchouing P: Antihypertensive and antioxidant effects of Allanblackia floribunda Oliv.(Clusiaceae) aqueous extract in alcohol- and sucrose-induced hypertensive rats. J Ethnopharmacol 2010, 128:634-640.

12. Hilditch TP, Marea ML, Zaky YAH: The fatty acids and glycerides of seed fats of Allanblackia floribunda and Allanblackia parviflora. J Soc Chem Ind 1940, 59:25.

13. Bonanome A, Grundy SM: Effect of dietary stearic acid on plasma cholesterol and lipoprotein levels. New Eng J Med 1988, 318:1244-1248.

14. Atangana AR, van der Vlis E, Khasa DP, van Houten D, Beaulieu J, Hendrickx H: Tree-to-tree variation in stearic and oleic acid content in seed fat from Allanblackia floribunda from wild stands: potential for tree breeding. Food Chem 2011, 126:1579-1585.

15. Nasri N, Triki S: Storage proteins from seeds of Pinus pinea L. C. R. Biol 2007, 330:402-409.

16. Bradford M: A rapid and sensitive method for the quantification of microgram quantities of protein utilizing the principle of protein-dye binding. Anal Biochem 1976, 72:248-254.

17. Laemmli VK: Cleavage of structural proteins during the assembly of the heat of bacteriophage T4. Nature 1970, 227:680-685.

18. AOAC: The definition of dietary fiber. Cereal Foods World 2001, 46:112-126.

19. Dicka MH, Gruppen H, Voragen AGJ, Van Berkel WJH: Comparison of content in phenolic compounds, polyphenol oxidase and peroxidase in grains of fifty sorghum varieties from Burkina Faso. J Agric Food Chem 2002, 50:3780-3788.

20. Singleton $V L$, Orthofer R, Lamuela-Raventos RM: Analysis of total phenols and other oxidant substrates and antioxidants by means of Folin-Ciocalteu reagent. Meth Enz 1999, 299:152-178.

21. Benzie IFF, Strain JJ: The ferric reducing ability of plasma (FRAP) as a measure of "antioxidant power": the FRAP assay. Anal Biochem 1996, 239:70-76

22. Katalinie V, Milos M, Modun D, Musi I, Boban M: Antioxidant effectiveness of selected wines in comparison with (+) - catechin. Food Chem 2003, 86:593-600.

23. Re R, Pellegrini AA, Pannala A, Yang M, Rice-Evans C: Antioxidant activity applying an improved ABTS radical cation decolorization assay. Free Rad Biol Med 1999, 26:1231-1237.

24. Dinis TCP, Madeira VMC, Almeida LM: Action of phenolic derivates (acetoaminophen, salycilate, and 5-aminosalycilate) as inhibitors of membrane lipid peroxidation and peroxyl radicals scavengers Metal chelating activities: inhibition of the complexes ferrozine-ferrous irons. Arch Biochem Biophy 1994, 315:161-169.

25. Rabetafika HN, Van Remootel V, Danthine S, Paquot M, Blecker C: Flaxseed proteins: food uses and health benefits. Int J Food Sci Tech 2011 46:221-228.

26. Akintayo ET: Characteristics and composition of Parkia biglobbossa and Jatropha curcas oils and cakes. Bioresour Technol 2004, 92:307-310.

27. Matthaüs B: Antioxidant activity of extracts obtained from residues of different oilseeds. J Agri Food Chem 2002, 50:3444-3452.

28. Terpinc P, Ceh B, Poklar NU, Abramovic H: Studies of the correlation between antioxidant properties and the total phenolic content of different oil cake extracts. Ind Crop Prod 2012, 39:210-217.

29. Malencic D, Maksimovic Z, Popovic M, Miladinovic J: Polyphenol contents and antioxidant activity of soybean seed extracts. Bioresour Technol 2008 99:6688-6691.

30. Mariod AA, Ramlah MI, Maznah I, Norsharina I: Antioxidant activity and phenolic content of phenolic rich fractions obtained from black cumin (Nigella sativa) seedcake. Food Chem 2009, 116:306-312.

31. Kumar S, Sharma UK, Sharma AK, Pandey AK: Protective efficacy of Solanum xanthocarpum root extracts against free radical damage: phytochemical analysis and antioxidant effect. Cell Mol Biol 2012, 58:174-181.

32. Kumar S, Mishra A, Pandey AK: Antioxidant mediated protective effect of Parthenium hysterophorus against oxidative damage using in vitro models. BMC Comp Alt Med 2013, 13:120.

33. Karadag A, Ozcelik B, Saner S: Review of methods to determine antioxidant capacities. Food Anal Meth 2009, 2:41-60. 
34. Glore SR, Van Treeck DV, Knehaus AW, Guild M: Soluble fiber and serum lipids: a literature review. J Am Diet Assoc 1994, 94:425-436.

35. Marambe P, Shand P, Wanasundara P: An in-vitro investigation of selected biological activities of hydrolysed flaxseed (Linum usitatissimum L.) proteins. J Amer Oil Chem Soc 2008, 85:1155-1164.

36. Kim HK, Choi S, Choi H: Suppression of hepatic fatty acid synthase by feeding a-linolenic acid rich perilla oil lowers plasma triacylglycerol level in rats. J Nutr Biochem 2004, 15:485-492.

doi:10.1186/1472-6882-13-352

Cite this article as: Boudjeko et al.: Partial characterization, antioxidative properties and hypolipidemic effects of oilseed cake of Allanblackia floribunda and Jatropha curcas. BMC Complementary and Alternative Medicine 2013 13:352.

\section{Submit your next manuscript to BioMed Central and take full advantage of:}

- Convenient online submission

- Thorough peer review

- No space constraints or color figure charges

- Immediate publication on acceptance

- Inclusion in PubMed, CAS, Scopus and Google Scholar

- Research which is freely available for redistribution 